\title{
ANTITUMOR AND GASTROPROTECTIVE SCREENING OF SOME NOVEL ORGANIC DERIVATIVES OF BISMUTH
}

\author{
DIPTI MANI TRIPATHI, RAVI KANT, KRISHNA SRIVASTAVA* \\ Department of Chemistry, Faculty of Chemical Sciences, Shri Ramswaroop Memorial University, Lucknow, Uttar Pradesh India. \\ Email: Krishna.cy@srmu.ac.in
}

Received: 16 December 2019, Revised and Accepted: 29 February 2020

\begin{abstract}
Objectives: The objectives of present manuscript are to synthesize some new organic derivatives of bismuth having general formula (RBiL $L_{2}$, wherein $\mathrm{R}=\mathrm{C}_{6} \mathrm{~F}_{5} ; \mathrm{L}=$ Substituted aromatic carboxylic acid), and characterized with the help of M.P., elemental, I.R., and NMR spectral analysis to ascertain the structure of novel compounds. These compounds were also characterized for their in vitro antitumor activity against human breast (MCF-7) and mammary cancer (EVSA-7) cell line along with gastroprotective (anti-ulcer) activity in rats using standard methods.
\end{abstract}

Methods: All the newly organobismuth having general formula $\left(\mathrm{RBiL}_{2}\right)$ were synthesised by earliar reported methods especially using redistribution and complexation reactions. The in-vitro antitumor and gastroprotective studies were performed by using standard protocols and methods.

Results: It was found that the compounds were crystalline solids, air stable, and soluble in common organic solvent, have sharp melting points, and possess trigonal/pyramidal structure, exhibit higher activity than the standard ranitidine when the tests were carried out with aspirin induced and moderate activity was seen when the tests were done with ethanol induced along with potential antitumor activity against MCF-7 and EVSA-7 cell lines.

Conclusion: The newly synthesized organobismuth complexes were characterized to ascertain their structure by sophisticated instrumental and spectral analysis resulted as trigonal/pyramidal structure. The compounds were also screened $1^{\text {st }}$ time for gastroprotective and antitumor activity in vitro. The observations clearly indicate that organobismuth carboxylates as reported here show potential gastroprotective and antitumor activity in vitro.

Keywords: Organobismuth, Antitumor, Antiulcer, Gastroprotective activity.

(C) 2020 The Authors. Published by Innovare Academic Sciences Pvt Ltd. This is an open access article under the CC BY license (http://creativecommons. org/licenses/by/4. 0/) DOI: http://dx.doi.org/10.22159/ajpcr.2020.v13i5.36622

\section{INTRODUCTION}

It is seen in past few years that metal-based drugs have taken more attention of researchers due to their higher efficacy against different acute and pathogenic diseases in all over the world, especially in developing countries. Organometallic drugs are recently used significantly in medical field for the treatment of precarious diseases such as tumor and cancer along with the treatment of malaria, syphilis, severe burns, leishmaniasis, trypanosomiasis, manic depressive psychosis, rheumatoid arthritis etc. It was recently found that organobismuth compounds were active against the treatment of gastrointestinal disorders such as dyspepsia, diarrhea, and in peptic ulcers by inhibiting Escherichia coli [1-7]. Recently, it was found that these salts are useful for Helicobacter pylori eradication therapy, (H. pylori now well known for the formation of gastrointestinal ulcer in human beings and organobismuth compounds are the only cure against this bacteria) and therefore promoted for the microbial studies of various organobismuth compounds [8-11]. The synergic administration of cisplatin and bismuth compounds is well known to reduce the toxic side effects of cisplatin, an effect that may trace to increase the production of metallothionein induced by bismuth compounds [12-15]. The present manuscript deals the antitumor and gastroprotective studies of novel organobismuthanes in +3 oxidation states which are indeed screen $1^{\text {st }}$ time for biomedicinal perspectives.

\section{METHODS}

All the newly organobismuth having general formula $\left(\mathrm{RBiL}_{2}\right)$ were synthesised by earliar reported methods especially using redistribution and complexation reactions. The in-vitro antitumor and gastroprotective studies were performed by using standard protocols and methods.

\section{RESULTS AND DISCUSSION}

The organobismuth compounds were synthesized by earlier reported methods and all the solvents and reagents were purified and recrystallized before use. The new compounds were crystalline solids, air stable, and soluble in common organic solvents. They were further characterized by their melting points and analytical techniques such as elemental analysis, infrared and NMR spectroscopy to ascertain their structures and explore their biological and toxicological properties. The new compounds have sharp melting points and possess trigonal/pyramidal structure as per results obtained by further analysis.

\section{IR and NMR spectral analysis}

The IR spectra of new fluorophenyl bismuthanes were recorded in PerkinElmer spectrophotometer in $4000-200 \mathrm{~cm}^{-1}$ range. The IR spectra of these compounds show absorption bands due to pentafluorophenyl groups. The absorption frequencies have been fully assigned. The $\mathrm{Bi}-\mathrm{C}$ vibration in case of pentafluorophenyl derivatives corresponding to the " $y$ " mode appears in the range of $440-460 \mathrm{~cm}^{-1}$. The IR data suggested a monodentate coordination mode of the substituted aromatic acids as ligands. The ${ }^{1} \mathrm{H}$ NMR spectra of the representative pentafluorophenylbismuth (III)dicarboxylates showed a multiplet in the range $\delta 7.84-\delta 8.16 \mathrm{ppm}$, which could be assigned to aromatic protons. The ${ }^{19} \mathrm{FNMR}$ spectra of the compound were carried out at room temperature and the compounds showed peaks appearing in the approximate range consistent with the presence of fluorophenyl groups (Table 1).

\section{Antitumor activity}

The antitumor activity of these compounds was studied against the human breast adenocarcinoma (MCF-7) and mammary cancer (EVSA-7) cell lines. The compounds show moderate to high activity against tumor cell lines (Table 
2). It was found that these compounds are in +3 oxidation state and the slight variation in their activity is due to presence of different substituted carboxylates groups along with presence of fluorine on main moiety of the compound. The compounds generally interact with the receptor site of multienzyme complex responsible for the cytostatic and cytotoxic conditions. The compounds in +3 oxidation state can easily bind with the receptor site. It may be noted that these compound generally binds with nitrogen 7 position of purine bases in DNA molecule and form complexes with DNA strands affecting replication and transcription of DNA molecule and stop the cell division along with protein synthesis.

\section{Gastroprotective (anti-ulcer) activity}

The anti-ulcer activity of all the organobismuth (III) compounds was performed on Sprague Dawley rats (140-180 g). The compounds exhibit higher activity than the standard ranitidine when the tests were carried out with aspirin (ASP) induced and moderate activity was seen when the tests were done with ethanol (EtOH) induced (Table 3). It was known that ASP caused mucosal damage by interrupting the synthesis of prostaglandin and increasing acid secretion and back diffusion of $\mathrm{H}^{+}$ions, which results in overproduction of leukotrienes and other products of 5-lipoxygenase pathway. Hence, the protective action of these compounds against ASP-induced gastric ulcer could possibly be due to its inhibitory effect on 5-lipoxygenase enzyme pathway. In case of EtOH-induced, ulcer which is predominantly occurs at glandular part of stomach was reported to stimulate the formation of leukotrienes $\mathrm{C}-4$, mast cell secretary products and reactive oxygen species, which results in the damage of gastric mucosa of rat. The organobismuth (III) substituted carboxylates possibly play important roles in inhibition of these pathways and show better activity in comparison to standard.

\section{Experimental}

The organobismuth compounds were obtained by reported method [16]. The ligands were recrystallized before use, while the reactions were performed under inert/nitrogen atmosphere.

$$
\begin{gathered}
\mathrm{R}_{3} \mathrm{M}+\mathrm{MCl}_{3} \underset{\mathrm{Et}_{3} \mathrm{~N}}{\stackrel{\text { Neat }}{\longrightarrow}} \mathrm{RMCl}_{2} \\
\mathrm{RMCl}_{2}+\mathrm{HL} \rightarrow \mathrm{RML}_{2}+2 \mathrm{Et}_{3} \mathrm{~N} \cdot \mathrm{HCl}
\end{gathered}
$$

\section{$\mathrm{R}=\left(\mathrm{C}_{6} \mathrm{~F}_{5}\right) ; \mathrm{M}=\mathrm{Bi} ; \mathrm{HL}=$ (Substituted aromatic carboxylic acid $)$.}

The general method of preparation clearly demonstrated that in an oxygen free nitrogen atmosphere, solution of pentafluorophenyl)

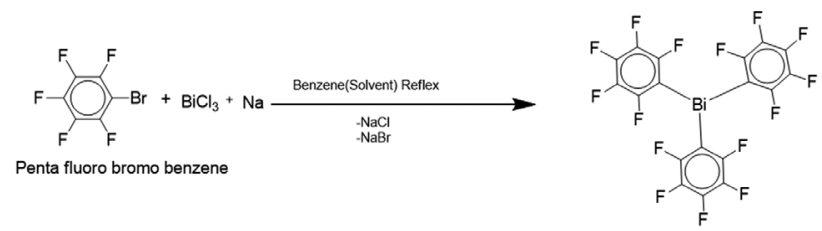

Tris (Penta fluoro phenyl) Bismuth

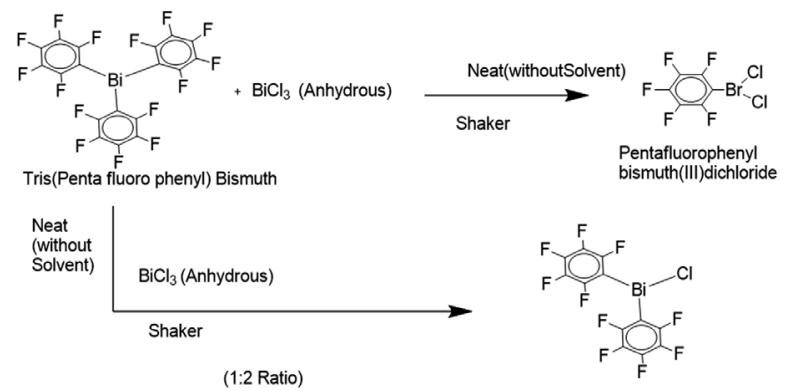

Bis(Pentafluorophenyl) Bismuth(III) chloride

bismuth(III) dichloride ( $1 \mathrm{mmol}$ ) in benzene and substituted aromatic acid $(2 \mathrm{mmol})$ in same solvent was stirred together in the presence of triethylamine at room temperature for $6 \mathrm{~h}$. The off-white color $\mathrm{Et}_{3} \mathrm{~N}$. $\mathrm{HCl}$ was formed (M.P. $=240^{\circ} \mathrm{C}$ ), which was filtered off and the filtrate on evaporation in vacuum gives an off-white color crystalline solid which was further recrystallized in pet ether. All the compounds were recrystallized before subjected to biological activity.

\section{Antitumor activity}

The in vitro antitumor studies were performed by 3-(4,5-dimethylthiazol-2yl)-2,5,-diphenyltetrazoleumbromide (MTT) method [17]. This method was carried out to estimate the effect of test compound on the growth of tumor cells in vitro. The human breast cancer (MCF-7) and mammary cancer (EVSA-7) cell lines were used for the evaluation of this activity. The cell lines were coincubated with the test compounds at $1 \mathrm{mg} / \mathrm{ml}$ doses for 96 $\mathrm{h}$ and the cell growth count was measured. The basic principle involved in this assay depends on the reduction of tetrazoleum salt. The yellow-colored

\begin{tabular}{|c|c|c|c|c|c|}
\hline \multirow[t]{2}{*}{ S. No. } & \multirow[t]{2}{*}{ Compounds } & \multirow[t]{2}{*}{ Yield \% } & \multirow[t]{2}{*}{ M.P ${ }^{\circ} \mathrm{C}$} & \multicolumn{2}{|l|}{$\operatorname{IR}\left(\mathrm{cm}^{-1}\right)$} \\
\hline & & & & $v_{\text {asym }}(\mathbf{C O})$ & $v_{\text {sym }}$ (CO) \\
\hline 1. & $\left(\mathrm{C}_{6} \mathrm{~F}_{5}\right) \mathrm{Bi}\left(\mathrm{OOCC}_{6} \mathrm{H}_{4} \mathrm{NO}_{2}\right)_{2}$ & 72 & 68 & $1724 \mathrm{vs}$ & $1326 \mathrm{~ms}$ \\
\hline 2. & $\left(\mathrm{C}_{6}^{6} \mathrm{~F}_{5}^{5}\right) \mathrm{Bi}\left(\mathrm{OOCC}_{6}^{6} \mathrm{H}_{4}^{4} \mathrm{NO}_{2}\right)_{2}$ & 70 & 64 & $1730 \mathrm{vs}$ & $1334 \mathrm{~ms}$ \\
\hline 3. & $\left(\mathrm{C}_{6}^{0} \mathrm{~F}_{5}\right) \mathrm{Bi}\left(\mathrm{OOCC}_{6} \mathrm{H}_{4} \mathrm{Cl}_{2}\right.$ & 75 & 66 & $1732 \mathrm{~ms}$ & $1330 \mathrm{~ms}$ \\
\hline 4. & $\left(\mathrm{C}_{6}^{6} \mathrm{~F}_{5}^{5}\right) \mathrm{Bi}\left(\mathrm{OOCC}_{6}^{6} \mathrm{H}_{4}^{4} \mathrm{Cl}\right)_{2}^{2}$ & 76 & 67 & 1709 vs & $1306 \mathrm{~ms}$ \\
\hline 5. & $\left(\mathrm{C}_{6} \mathrm{~F}_{5}\right) \mathrm{Bi}\left(\mathrm{OOCC}_{6} \mathrm{H}_{4} \mathrm{NH}_{2}\right)_{2}$ & 68 & 68 & $1726 \mathrm{~ms}$ & $1325 \mathrm{~ms}$ \\
\hline 6. & $\left(\mathrm{C}_{6}^{6} \mathrm{~F}_{5}^{5}\right) \mathrm{Bi}\left(\mathrm{OOCC}_{6}^{6} \mathrm{H}_{4}^{4} \mathrm{NH}_{2}\right)_{2}$ & 68 & 67 & 1729 vs & $1327 \mathrm{~ms}$ \\
\hline 7. & {$\left[\left(\mathrm{C}_{6} \mathrm{~F}_{5}\right) \mathrm{Bi}\left(\mathrm{OOCC}_{6} \mathrm{H}_{3}(\mathrm{OH}) \mathrm{OCH}_{3}\right]_{2}\right.$} & 72 & 62 & $1758 \mathrm{vs}$ & $1356 \mathrm{~ms}$ \\
\hline
\end{tabular}

Table 1: Physicochemical studies

\begin{tabular}{|c|c|c|c|c|}
\hline S. No. & Compounds & MCF-7 (cell no. $\times 10^{4}$ ) & EVSA-7 (cell no. × 10 ${ }^{4}$ ) & Activity \\
\hline 1. & $\left(\mathrm{C}_{6} \mathrm{~F}_{5}\right) \mathrm{Bi}\left(\mathrm{OOCC}_{6} \mathrm{H}_{4} \mathrm{NO}_{2}\right)_{2}$ & $9.19 \pm 0.92$ & $9.29 \pm 0.88$ & Positive \\
\hline 2. & $\left(\mathrm{C}_{6}^{6} \mathrm{~F}_{5}^{5}\right) \mathrm{Bi}\left(\mathrm{OOCC}_{6}^{6} \mathrm{H}_{4}^{4} \mathrm{NO}_{2}\right)_{2}$ & $9.17 \pm 0.90$ & $8.67 \pm 0.69$ & Positive \\
\hline 3. & $\left(\mathrm{C}_{6} \mathrm{~F}_{5}\right) \mathrm{Bi}\left(\mathrm{OOCC}_{\mathrm{H}} \mathrm{H}_{4} \mathrm{Cl}\right)_{2}$ & $9.29 \pm 0.88$ & $9.89 \pm 0.92$ & Positive \\
\hline 4. & $\left(\mathrm{C}_{6}^{0} \mathrm{~F}_{5}\right) \mathrm{Bi}\left(\mathrm{OOCC}_{6}^{\circ} \mathrm{H}_{4}^{4} \mathrm{Cl}\right)_{2}$ & $8.95 \pm 0.67$ & $8.55 \pm 0.62$ & Positive \\
\hline 5. & $\left(\mathrm{C}_{6}^{6} \mathrm{~F}_{5}^{5}\right) \mathrm{Bi}\left(\mathrm{OOCC}_{6}^{6} \mathrm{H}_{4}^{4} \mathrm{NH}_{2}\right)_{2}$ & $8.79 \pm 0.52$ & $8.42 \pm 0.46$ & Positive \\
\hline 6. & $\left(\mathrm{C}_{6} \mathrm{~F}_{5}\right) \mathrm{Bi}\left(\mathrm{OOCC}_{6} \mathrm{H}_{4} \mathrm{NH}_{2}\right)_{2}$ & $9.19 \pm 0.92$ & $9.29 \pm 0.88$ & Positive \\
\hline 7. & {$\left[\left(\mathrm{C}_{6} \mathrm{~F}_{5}\right) \mathrm{Bi}\left(\mathrm{OOCC}_{6} \mathrm{H}_{3}(\mathrm{OH}) \mathrm{OCH}_{3}\right]_{2}\right.$} & $9.17 \pm 0.92$ & $8.68 \pm 0.70$ & Positive \\
\hline 10. & Negative control & $10.21 \pm 1.01$ & $10.22 \pm 1.01$ & - \\
\hline 11. & Positive control & $40.26 \pm 3.23$ & $41.23 \pm 3.28$ & - \\
\hline
\end{tabular}

Table 2: Antitumor studies (in vitro)

${ }^{*}$ Negative control - Culture medium only, ${ }^{* *}$ Positive control - $17 \beta$ estradiol 
Table 3: Anti-ulcer activity

\begin{tabular}{|c|c|c|c|c|c|}
\hline \multirow[t]{2}{*}{ S. No. } & \multirow[t]{2}{*}{ Compounds } & \multicolumn{2}{|l|}{ Aspirin induced } & \multicolumn{2}{|l|}{ Ethanol induced } \\
\hline & & Ulcer index $\left(\mathrm{mm}^{2} /\right.$ rat $)$ & Protective ratio (\%) & Ulcer index $\left(\mathrm{mm}^{2} / \mathrm{rat}\right)$ & Protective ratio (\%) \\
\hline 1. & $\left(\mathrm{C}_{6} \mathrm{~F}_{5}\right) \mathrm{Bi}\left(\mathrm{OOCC}_{6} \mathrm{H}_{4} \mathrm{NO}_{2}\right)_{2}$ & $7.2 \pm 0.58$ & 61.68 & $19.9 \pm 5.4$ & 18.21 \\
\hline 2. & $\left(\mathrm{C}_{6} \mathrm{~F}_{5}\right) \mathrm{Bi}\left(\mathrm{OOCC}_{6} \mathrm{H}_{4} \mathrm{NO}_{2}\right)_{2}$ & $7.2 \pm 0.58$ & 61.68 & $19.7 \pm 5.2$ & 18.17 \\
\hline 3. & $\left(\mathrm{C}_{6}^{6} \mathrm{~F}_{5}\right) \mathrm{Bi}\left(\mathrm{OOCC}_{6}^{6} \mathrm{H}_{4}^{4} \mathrm{Cl}\right)_{2}$ & $7.1 \pm 0.54$ & 61.21 & $19.8 \pm 5.5$ & 18.18 \\
\hline 4. & $\left(\mathrm{C}_{6} \mathrm{~F}_{5}\right) \mathrm{Bi}\left(\mathrm{OOCC}_{6} \mathrm{H}_{4} \mathrm{Cl}\right)_{2}$ & $7.3 \pm 0.58$ & 61.72 & $19.8 \pm 5.4$ & 31.24 \\
\hline 5. & $\left(\mathrm{C}_{6}^{6} \mathrm{~F}_{5}^{5}\right) \mathrm{Bi}\left(\mathrm{OOCC}_{6}^{6} \mathrm{H}_{4}^{4} \mathrm{NH}_{2}\right)_{2}$ & $6.2 \pm 0.28$ & 62.16 & $14.4 \pm 2.2$ & 34.70 \\
\hline 6. & $\left(\mathrm{C}_{6} \mathrm{~F}_{5}\right) \mathrm{Bi}\left(\mathrm{OOCC}_{6} \mathrm{H}_{4} \mathrm{NH}_{2}\right)_{2}$ & $7.2 \pm 0.54$ & 61.68 & $19.6 \pm 5.3$ & 33.72 \\
\hline 7. & {$\left[\left(\mathrm{C}_{6} \mathrm{~F}_{5}\right) \mathrm{Bi}\left(\mathrm{OOCC}_{6} \mathrm{H}_{3}(\mathrm{OH}) \mathrm{OCH}_{3}\right]_{2}\right.$} & $7.1 \pm 0.54$ & 61.22 & $19.8 \pm 5.5$ & 18.16 \\
\hline 8. & Ranitidine & $7.6 \pm 0.53$ & 58.46 & $10.3 \pm 3.3$ & 57.43 \\
\hline 9. & Aspirin & $18.3 \pm 1.6$ & - & - & - \\
\hline 10. & Ethanol & - & & $24.2 \pm 6.5$ & - \\
\hline
\end{tabular}

tetrazoleum MTT is reduced by metabolically active cells in part by the action of dehydrogenase enzymes to generate reducing equivalents such as NADH and NADPH. The resulting intracellular purple color zones were solubilized and quantified by spectrophotometer method. The MTT was dissolved in phosphate buffer saline at a concentration of $5 \mathrm{mg} / \mathrm{ml}$. Then, $50 \mathrm{ml}$ of the MTT solution was added to each well of the 96 well culture plate, containing $100 \mathrm{ml}$ culture along with test compound and incubated at $37^{\circ} \mathrm{C}$ for $4 \mathrm{~h}$. The medium was then removed carefully without disturbing the purple-colored formazon crystals. Then, $50 \mathrm{ml}$ of dimethyl sulfoxide was added to each well and mixed thoroughly to dissolve the crystals of the formazon. The plates were then read on ELISA plate reader at a wavelength of $570 \mathrm{~nm}$. The readings were presented as optical density/cell count to evaluate the activity.

\section{Gastroprotective (anti-ulcer) activity}

The gastroprotective activity of newly synthesized organobismuth compounds was performed in rats using standard methods [18]. In the experiment, rats were divided into four groups (each group contains six rats). Group 1 was control group which received suspension of $1 \%$ carboxymethyl cellulose in distilled water $(10 \mathrm{ml} / \mathrm{kg})$. Groups 2 and 3 received samples dose of 25 and $50 \mathrm{mg} / \mathrm{kg}$ body weight. Group 4 received ranitidine salt in the dose of $50 \mathrm{mg} / \mathrm{kg}$ body weight. These all were administered orally twice daily at 10.00 and $16.00 \mathrm{~h}$, respectively, for 5 days for acute ulcer protective studies.

\section{ASP-induced ulcers}

ASP in dose of $200 \mathrm{mg} / \mathrm{kg}(20 \mathrm{mg} / \mathrm{ml})$ was administered to the animals on the day of the experiment and ulcers were scored after $4 \mathrm{~h}$. The animals were sacrificed and the stomach was then excised and cut along the greater curvature, washed carefully with $5 \mathrm{ml}$ of $0.9 \%$ NACL and ulcers were scored by a person unaware by the experimental protocol in the glandular portion of the stomach. Ulcer index was calculated by adding the total number of ulcers/stomach and total severity of ulcers/stomach. The pooled group ulcer score was then calculated by reported method.

\section{Ethanol (EtOH)-induced ulcers}

The gastric ulcers were induced in rats by administering EtOH $(1 \mathrm{ml} / 200 \mathrm{~g} / \mathrm{kg}$ for $1 \mathrm{~h}$ ) and the animals were sacrificed by cervical dislocation and the stomach was incised along the greater curvature and examined for ulcers. The ulcer index was scored, based on the product of length and width of the ulcers present in the glandular portion of the stomach $\left(\mathrm{mm}^{2} /\right.$ rats)

\section{CONCLUSION}

The newly synthesized organobismuth (III) dicarboxylates show trigonal/ pyramidal structure as per elemental and spectral analysis. The compounds were also show potential antitumor and gastroprotective activity.

\section{ACKNOWLEDGMENT}

The authors are thankful to the Vice-Chancellor, Shri Ramswaroop Memorial University, Lucknow-Deva Road, Uttar Pradesh for providing necessary laboratory facilities, the Director, Helix Biogenesis, Pvt. Ltd. Noida for carrying out biomedicinal activity.

\section{AUTHORS' CONTRIBUTIONS}

One of the authors Dipti Mani Tripathi worked as research scholar under the supervision of rest two authors Ravi Kant and Krishna Srivastava to complete this research work.

\section{CONFLICTS OF INTEREST}

There are no conflicts of interest.

\section{AUTHORS FUNDING}

The research work performed by authors by self-financial scheme and no financial assistance received from any funding agencies.

\section{REFERENCES}

1. Singh S, Hasan SM, Kant R. An overview of chemical properties and pharmacological importance of organobismuth compounds. Chron Pharm Sci 2018;2:35-45

2. Rani P, Gupta P, Kant R. Biomedicinal aspects of group-15 elements (As, Sb, Bi). Int J Chem Res 2017;9:201-8.

3. Rani P, Gupta P, Kant R. Synthesis, characterization and biological screening of some novel complexes of group 15 elements (As, Sb, Bi). Int J Microbiol Res 2017;9:984-6.

4. Rani P, Gupta P, Kant R. Synthesis and characterization of some novel complexes of fluorobenzoic acid with group-15 elements (As, Sb, Bi) for antimicrobial and antitumor studies. Int J Drug Discov 2017;8:250-3.

5. Gupta P, Rani P, Kant R. Antimicrobial studies of some novel organobismuth compounds. Int J Microbiol Res 2018;10:773-5.

6. Gupta P, Rani P, Kant R. Synthesis, characterization and antimicrobial studies of novel organobismuth (III) complexes. Int J Microbiol Res 2018;10:1086-9.

7. Soni KK, Kant R, Kumar A. Synthesis and characterization of novel organobismuth compounds: Antimicrobial and antitumor studies. Int J Chem Res 2015;7:159-63.

8. Soni KK, Kant R, Kumar A. Biomedicinal and gastroprotective studies of some fluorine based diorganobismuth (III) compounds. Int J Chem Res 2016;8:168-72.

9. Tripathi DM, Amresh G, Kant R. Bio-medicinal studies of some new triorganobismuth (V) compounds. Int J Chem Res 2012;4:110-3.

10. Tripathi DM, Amresh G, Kant R. Antimicrobial and antitumor studies of some organic derivatives of bismuth. J Med Chem Lett 2011;1:1-6.

11. Tiwari VK, Shukla SK, Chauhan VS, Kant R, Rani S, Tewari IC. Antimicrobial, antitumor and gastro protective studies of some new water soluble organic derivatives of bismuth. Int J Pharma Anal 2010;2:9-14.

12. Chauhan VS, Tiwari VK, Shukla SK, Rani S, Mishra SN, Kant R, et al. Biological activity of some organic derivatives of bismuth. Int $\mathrm{J}$ Biotechnol Res 2009;2:67-71.

13. Kant R, Srivastava K, Singh S, Hasan SM, Srivastava J. Organobismuth Compounds for Medical Applications and Preparation Methods Thereof. New Delhi: Indian Patent; 2018.

14. Srivastava K, Kant R. Novel Antitumor Organobismuth Compound and Method of Preparation Therof. New Delhi: Indian Patent; 2019. 
15. Chandrasekhar K, Behl HM, Sidhu OP, Ch VR, Pushpangadan P, Kant $\mathrm{R}$, et al. A Novel Compound as Insecticidal and its Processing. United States: PCT (Global) Patent; 2006.

16. Singhal K, Kant R, Goswami AK, Raj P. Synthesis and characterization of bis (pentafluorophenyl) antimony (V) cations $\left[\left(\mathrm{C}_{6} \mathrm{~F}_{5}\right)_{2} \mathrm{SbL}_{3}\right]^{3+}$. J Flourine Chem 2003;122:229-32
17. Kant R, Amresh G, Chandrashekar K, Shukla SK. Biological studies of some perfluorophenyl antimony compounds. Phosphorus Sulfur Silicon Relat Elem 2009;184:2453-64.

18. Amresh G, Husain Z, Gupta RJ, Kant R, Rao CV, Singh PN. Gastroprotective effects of ethanolic extract from Cissampelos pareira in experimental animals. J Nat Med 2007;61:323-8. 